\title{
Analisa Kebutuhan Sebagai Konsep Dasar Dalam Pengembangan Kurikulum Bahasa Arab di MAN Curup
}

\author{
Nurjannah \\ Sekolah Tinggi Agama Islam Negeri (STAIN) Curup \\ nurjanah@gmail.com
}

\begin{abstract}
Needs analysis in curriculum development is necessary to assess and identify the needs of Arabic and community teachers in curriculum development, as curriculum development is essentially oriented to the needs of Arabic language teachers and the needs of the community, including the needs of the subject. Needs analysis is also used to identify the incompatibility between the performance of the desired Arabic teacher and the performance of the real Arabic teacher. In the school system Needs analysis is needed to find curriculum deficiencies that involve school community collaboration and understanding of school programs for improvement. The purpose of the curriculum needs analysis is to find the right solution to solve the curriculum problem. One of the basic assumptions of curriculum development in education should be based on student needs analysis. The procedure used to collect information about student needs is known as needs analysis. The method of needs analysis in curriculum development is made to be able to measure the level of gap that occurs in student learning from what is expected and what has been obtained. The conclusions obtained in the analysis are: the needs of the curriculum is a formal process to determine the distance or gap between what exists and how should be from a curriculum, the priority of the main problem and then solved the problem. Needs analysis is a constructive and positive tool for making changes based on rational logic, functional changes that can meet the needs of citizens, groups and individuals.
\end{abstract}

Keywords: Needs Analysis, Curriculum, Arabic Language

\begin{abstract}
Abstrak
Analisis kebutuhan dalam pengembangan kurikulum sangat diperlukan untuk menilai dan mengidentifikasi kebutuhan-kebutuhan yang diperlukan guru bahasa arab dan masyarakat dalam pengembangan kurikulum, karena pengembangan kurikulum hakekatnya berorientasi pada kebutuhan guru bahasa arab dan kebutuhan masyarakat, termasuk kebutuhan mata pelajaran. Analisis kebutuhan juga digunakan untuk mengidentifikasi ketidak sesuaian antara performansi guru bahasa arab yang diinginkan dengan performansi guru bahasa arab yang nyata. Dalam sistem
\end{abstract}


persekolahan Analisis kebutuhan diperlukan untuk menemukan kekurangan-kekurangan kurikulum yang menyangkut misalnya kerja sama komunitas sekolah dan pemahaman terhadap program-program sekolah untuk kemudian diperbaiki. Adapun tujuan dari analisis kebutuhan kurikulum adalah untuk mencari solusi yang tepat untuk memecahkan masalah kurikulum. Salah satu asumsi dasar pengembangan kurikulum dalam bidang pendidikan harus didasarkan pada analisis kebutuhan siswa. Prosedur yang digunakan untuk mengumpulkan informasi tentang kebutuhan siswa dikenal dengan analisis kebutuhan. Metode analisis kebutuhan dalam pengembangan kurikulum dibuat untuk bisa mengukur tingkat kesenjangan yang terjadi dalam pembelajaran siswa dari apa yang diharapkan dan apa yang sudah didapat. Adapun kesimpulan yang didapatkan dalam analisa adalah: kebutuhan kurikulum merupakan suatu proses formal untuk menentukan jarak atau kesenjangan antara seperti apa yang ada dan bagaimana seharusnya dari suatu kurikulum, diambil prioritas masalah utamanya lalu diselesaikan masalahnya. Analisis kebutuhan adalah alat yang konstruktif dan positif untuk melakukan perubahan yang didasarkan atas logika yang bersifat rasional, perubahan yang bersifat fungsional yang dapat memenuhi kebutuhan warga negara, kelompok dan individu.

Kata Kunci: Analisis Kebutuhan, Kurikulum, Bahasa Arab

\section{Pendahuluan}

Analisa kebutuhan yang sering diistilahkan dengan needs analysis atau needs assessment dalam pengajaran bahasa (asing) yang memasukkan unsurunsur kurikulum pengajaran bahasa yang di dalamnya menguraikan hal-hal yang berkaitan dengan analisis kebutuhan, rumusan tujuan, instrument dan lain-lain. Penelitian ini juga mencoba membahas dan mengkaji pengajaran bahasa secara lebih mendalam mengenai perspektif pengembangan kurikulum bahasa dari berbagai sisi. Fokus utama yang menjadi bahasan ini adalah bagaimana bentuk desain kurikulum pembelajaran bahasa dapat tergambar yang menyangkut needs analysis. Analisa atau analisis dalam kajian linguistik diartikan dengan sebuah kajian yang dilaksanakan terhadap sebuah bahasa guna meneliti struktur bahasa tersebut secara mendalam. Analisis juga diartikan dengan penyelidikan terhadap suatu peristiwa baik berupa karangan atau sebuah perbuatan untuk mengetahui keadaan yang sebenarnya dari segi sebab-musabab maupun duduk perkaranya. ${ }^{1}$

Sebagaimana yang kita ketahui bahwa kurikulum adalah segala pengalaman pendidikan yang diberikan oleh sekolah kepada seluruh anak didiknya, baik dilakukan didalam maupun di luar sekolah. Pengalaman anak

${ }^{1}$ Tim Redaksi Kamus Besar Bahasa Indonesia Edisi Ketiga, Kamus Besar Babasa Indonesia Edisi Ketiga, (Jakarta : Balai Pustaka, 2005), 43 
didik di sekolah diperoleh melalui mengikuti pelajaran dikelas, praktek keterampilan, latihan-latihan olahraga dan kesenian, karya wisata atau praktek di laboratorium. Sementara menurut pandangan tradisional, kurikulum adalah rencana pendidikan dan pengajaran atau program pendidikan. Karena kurikulum terdiri atas mata pelajaran tertentu yang harus diajarkan kepada siswa-i yang diambil dari buku-buku pelajaran tertentu yang dipandang baik. ${ }^{2}$

Perlunya Needs Analysis dalam Pengembangan Kurikulum Pengembangan kurikulum sebagaimana yang telah dibahas adalah serangkaian aktivitas yang memberi kontribusi terhadap tumbuhnya konsensus antara staf, guru, administrasi, dan para siswa. Rangkaian aktivitas kurikulum tersebut akan memberikan satu kerangka yang dapat membantu guru untuk menyelesaikan berbagai kombinasi aktivitas mengajar yang paling tepat dan profesional bagi satu situasi, dimana kerangka kerja tersebut juga membantu siswa dalam belajar secara efektif dan efisien. Artinya, bahwa proses desain kurikulum dapat dipandang sebagai sesuatu yang memudahkan guru dan siswa dapat melaksanakan kegiatan pembelajaran. Model kurikulum bahasa tidak hanya menggambarkan tentang literatur pengajaran bahasa saja, tetapi juga modelmodel umum yang digunakan untuk menjelaskan pendekatan sistem yang ditetapkan dalam desain kurikulum.

Kurikulum saat ini dirasakan mempunyai peran dan fungsi yang sangat kompleks. Hal ini disebabkan karena kurikulum merupakan alat yang krusial dalam merealisasikan program pendidikan, baik formal maupun non formal, sehingga gambaran sistem pendidikan dapat terlihat jelas dalam kurikulum tersebut. Sejalan dengan tuntutan zaman, perkembangan masyarakat dan kemajuan ilmu pengetahuan dan teknologi serta globalisasi, sudah saatnya dunia pendidikan memasuki masa inovasi dan berjalan mencapai sasarannya. Maka dalam hal ini analisis kebutuhan kurikulum sangat urgen, demi tercapainya rencana dan sasaran pengajaran dan pembelajaran.

Salah satu asumsi dasar pengembangan kurikulum dalam bidang pendidikan harus didasarkan pada analisa kebutuhan siswa. Prosedur yang digunakan untuk mengumpilkan informsi tentang kebutuhan siswa dikenal dengan analisis kebutuhan. Analisis kebutuhan sebagai tahap awalyang perlu dibedakan dalam perencanaan program bidang pendidikan.

Analisis kebutuhan ini dilakukan agar bagaimana dapat merancang prosedur yang digunakan untuk mengumpulkan informasi mengenai kebutuhan peserta didik. Namun seiring dengan perkembangannya, kurikulum masih saja mengalami perubahan sehingga tidak jarang terdapat kesenjangan didalam

${ }^{2}$ Suryosubroto, Manajemen Pendidikan Di Sekolah, (Jakarta : PT. Rineka Cipta, 2004), 32-33 
pelaksanaannya. Untuk itu dengan adanya analisis kebutuhan, maka akan dapat diketahui mengenai jarak kesenjangan, solusi dan penilaian kurikulum.

\section{Kurikulum}

Istilah kurikulum awal mulanya digunakan dalam dunia olah raga pada zaman Yunani Kuno. Curriculum dalam bahasa Yunani berasal dari kata Curir, artinya pelari dan Curere artinya tempat berpacu. Curriculum diartikan "jarak" yang harus "ditempuh" oleh pelari. ${ }^{3}$ Mengambil makna yang terkandung dari rumusan di atas, kurikulum dalam pendidikan diartikan sejumlah mata pelajaran yang harus ditempuh/disesuikan anak didik untuk memperoleh ijazah, ${ }^{4}$ sedangkan ijazah itu sendiri menggambarkan kemampuan. Oleh karena itu, hanya orang yang telah memperoleh kemampuan sesuai standar tertentu yang akan memperoleh ijazah. ${ }^{5}$ Sedangkan dalam bahasa Arab, kata kurikulum biasa diungkapkan dengan manhaj yang berarti jalan yang dilalui oleh manusia pada berbagai bidang kehidupan. Sedangkan, kurikulum pendidikan (manhaj aldirasah) dalam kamus Tarbiyah adalah seperangkat perencanaan dan media yang dijadikan acuan oleh lembaga pendidikan dalam mewujudkan tujuan-tujuan pendidikan. ${ }^{6}$

Dalam konteks pengembangan kurikulum, John McNeil mendefinisikan analisis kebutuhan (need assessment) sebagai: Proses dimana seseorang mendefinisikan kebutuhan pendidikan dan memutuskan apa prioritas mereka. Sejalan dengan pendapat McNeil, Seels dan Glasglow menjelaskan tentang pengertian need assessment: Itu berarti rencana untuk mengumpulkan Informasi tentang perbedaan dan untuk menggunakan informasi tersebut untuk membuat keputusan tentang prioritas.

Sedangkan menurut Anderson analisis kebutuhan diartikan sebagai suatu proses kebutuhan sekaligus menentukan prioritas. Need Assessment adalah suatu cara atau metode untuk mengetahui perbedaan antara kondisi yang diinginkan/seharusnya (harus/seharusnya menjadi) atau diharapkan dengan kondisi yang ada (apa yang). Kondisi yang diinginkan seringkali disebut dengan

${ }^{3}$ Nana Sudjana, Pembinaan dan Pengembagan Kurikulum di Sekolah, (Bandung; Sinar Baru Algensindo, 1988), h. 4

${ }^{4}$ Oemar Hamalik, Sistem dan Prosedur Pengembangan Kurikulum Lembaga Pendidikan dan Pelatihan, (Bandung: Trigenda Karya, 1983), h. 18

${ }^{5}$ Wina Sanjaya, Pembelajaran dalam Implementasi Berbasis Kompetensi,,Jakarta: Kencana Media Grup, 2006), h. 2

${ }^{6}$ Rusydi Ahmad Tha'imah, Ta'lim al-'Arabiyah li Gbairi al-Nutbiqina biha Manabiju wa Asalibubu, (Rabath: Mansyuror al-Munazzamahal-Islamiyah li Tarbiya wa al-'ulum wa alTsaafiyah, ISISCO, 1410H/1989 M), h. 59 
kondisi ideal, sedangkan kondisi yang ada, seringkali disebut dengan kondisi riil atau kondisi nyata.

Ada beberapa hal yang melekat pada pengertian need assessment. Pertama; needassessment merupakan suatu proses artinya ada rangkaian kegiatan dalam pelaksanaan need assessment. Need assessement bukanlah suatu hasil, akan tetapi suatu aktivitas tertentu dalam upaya mengambil keputusan tertentu. Kedua; kebutuhan itu sendiri pada hakikatnya adalah kesenjangan antara harapan dan kenyataan. Dengan demikian maka, need assessment merupakan kegiatan mengumpulkan informasi tentang kesenjangan yang seharusnya dimiliki setiap siswa dengan apa yang telah dimiliki.

Analisis kebutuhan merupakan alat yang konstruktif dan positif untuk melakukan perubahan. Perubahan yang didasarkan atas logika yang bersifat rasional, perubahan fungsional yang dapat memenuhi kebutuhan kelompok dan individu. Perubahan ini menunjukkan upaya formal yang sistematis menentukan dan mendekatkan jarak kesenjangan antara "seperti apa yang ada" dengan "bagaimana seharusnya". Need Assessment (analisis kebutuhan) adalah suatu cara atau metode untuk mengetahui perbedaan antara kondisi yang diinginkan/seharusnya (should be/ought to be) atau diharapkan dengan kondisi yang ada (what is). Metode Need Assessment dibuat untuk bisa mengukur tingkat kesenjangan yang terjadi dalam pembelajaran siswa dari apa yang diharapkan dan apa yang sudah didapat.

Analisis kebutuhan merupakan aktivitas ilmiah untuk mengidentifikasi faktorfaktor pendukung dan penghambat (kesenjangan) proses pembelajaran guna mencapai tujuan pembelajaran (goals and objectives) yang mengarah pada peningkatan mutu pendidikan. Roger Kaufman dan Fenwick W. English berpendapat bahwa analisis kebutuhan tidak dapat melepaskan diri dari pembicaraan sistem pendidikan secara keseluruhan. Dalam sistem pendidikan terdapat dua tema pokok yaitu manajemen dan kurikulum.

\section{Fungsi Analisis Kebutuhan Kurikulum}

Metode Need Assessment dibuat untuk bisa mengukur tingkat kesenjangan yang terjadi dalam pembelajaran siswa dari apa yang diharapkan dan apa yang sudah didapat. Dalam pengukuran kesenjangan seorang analisis harus mampu mengetahui seberapa besar masalah yang dihadapi. Beberapa fungsi Need Assessment menurut Morisson sebagai berikut:

1. Mengidentifikasi kebutuhan yang relevan dengan pekerjaan atau tugas sekarang yaitu masalah apa yang mempengaruhi hasil pembelajaran. 
2. Mengidentifikasi kebutuhan mendesak yang terkait dengan finansial, keamanan atau masalah lain yang menggangu pekerjaan atau lingkungan pendidikan.

3. Menyajikan prioritas-prioritas untuk memilih tindakan.

4. Memberikan data basis untuk menganalisa efektifitas pembelajaran

Ada enam macam kebutuhan yang biasa digunakan untuk merencanakan dan mengadakan analisa kebutuhan, yaitu:

1. Normatif

Membandingkan peserta didik dengan standar nasional, misal, UAN, SNMPTN, dan sebagainya.

Kebutuhan Komperatif,

Membandingkan peserta didik pada satu kelompok dengan kelompok lain yang selevel. Misal, hasil Ebtanas SLTP A dengan SLTP B.

2. Kebutuhan yang dirasakan,

Yaitu hasrat atau kinginan yang dimiliki masing-masing peserta didik yang perlu ditingkatkan. Kebutuhan ini menunjukan kesenjangan antara tingkat ketrampilan/kenyataan yang nampak dengan yang dirasakan. Cara terbaik untuk mengidentifikasi kebutuhan ini dengan cara interview.

3. Kebutuhan yang diekspresikan,

Yaitu kebutuhan yang dirasakan seseorang mampu diekspresikan dalam tindakan. Misal, siswa yang mendaftar sebuah kursus.

4. Kebutuhan Masa Depan,

Yaitu mengidentifikasi perubahan-perubahan yang akan terjadi dimasa mendatang. Misal, penerapan teknik pembelajaran yang baru, dan sebagainya.

5. Kebutuhan Insidentil yang mendesak,

Yaitu faktor negatif yang muncul di luar dugaan yang sangat berpengaruh. Misal, bencana nuklir, kesalahan medis, bencana alam, dan sebagainya.

\section{Langkah-Langkah Analisis Kebutuhan Kurikulum}

Glasgow menggambarkan need assessment dalam bentuk kegiatan yang dimulai dari tahapan pengumpulan informasi sampai merumuskan masalah. Sedangkan Morrison menggambarkan Need assessment dalam bentuk kegiatan 
yang dimulai dari perencanaan sampai membuat laporan akhir. Bentuk langkahlangkah need assessment menurut Glasgow sebagai berikut:

1. Tahapan pengumpulan Informasi; dalam tahapan ini seorang desainer harus bisa memahami dan mengumpulkan informasi dari para siswa cakupan pengumpulan informasi bisa beragam seperti karakteristik siswa, kemampuan personal, dan problematic didalam pembelajaran.

2. Tahapan identifikasi kesenjangan; menurut Kaufman mengidentifikasi kesenjangan yaitu dengan menggunakan metode Organizational Element Model yang dimana dalam metode ini menjelaskan adanya lima elemen yang saling berkaitan. Dimulai dari input-proses-produk-output-outcome.

3. Analisis Performa; tahapan ini dilakukan setelah desainer memahami berbagai informasi dan mengidentifikasi kesenjangan yang ada. Dalam hal ini ketika menemukan sebuah kesenjangan, diidentifikasi kesenjangan mana yang dapat dipecahkan melalui perencanaan pembelajaran dan mana yang memerlukan pemecahan yang lain.

4. Identifikasi Hambatan dan Sumber; dalam tahapan ini pelaksanaan suatu program berbagai kendala bisa muncul sehingga dapat berpengaruh terhadap kelancaran suatu program. Berbagai kendala bisa meliputi dari waktu, fasilitas, bahan, dan sebagainya. Sumber-sumbernya juga bisa dari pengorganisasian, fasilitas, dan pendanaan.

5. Identifikasi Karakteristik Siswa; tahapan ini merupakan proses pengidentifikasian masalah-masalah siswa. Karena Tujuan utama dalam desain pembelajaran adalah memecahkan berbagai masalah yang dihadapi siswa.

6. Identifikasi tujuan; mengidentifikasi tujuan merupakan salah satu tahapan penting yang ada didalam need assessment, karena mengidentifikasi tujuan merupakan proses penetapan kebutuhan yang dianggap mendesak untuk dipecahkan sesuai dengan kondisi, karena tidak semua kebutuhan menjadi tujuan.

7. Menentukan permasalahan; tahapan ini adalah tahap akhir dalam proses analisis, yaitu menuliskan pernyataan adalah sebagai pedoman dalam penyusunan proses desain instruksional. berikut:

Sedangkan menurut Morrison langkah-langkah need assessment sebagai

1. Perencanaan : yang perlu dilakukan; membuat klasifikasi siswa, siapa yang akan terlibat dalam kegiatan dan cara pengumpulannya. 
2. Pengumpulan data : perlu mempertimbangkan besar kecilnya sampel dalam penyebarannya (distribusi).

3. Analisa data : setelah data terkumpul kemudian data dianalisis dengan pertimbangan : ekonomi, rangking, frequensi dan kebutuhan.

4. Membuat laporan akhir : dalam sebuah laporan analisa kebutuhan mencakup empat bagian; analisa tujuan, analisa proses, analisa hasil dengan table dan penjelasan singkat, rekomendasi yang terkait dengan data.

\section{Analisis pengembangan kurikum berdasarkan kebutuhan}

Pengembangan kurikulum merupakan langkah dalam mengimbangi berkembangnya ilmu pengetahuan, teknologi, seni,psikologi, sosial politik, ekonomi, dan lain sebagainya. Sehingga pada akhirnya dapat memberikan gambaran mengenai arah dan tujuan dari produk kurikulum yang ada dan akan diimplementasikan oleh implementator kurikulum. Hal ini sejalan dengan pernyataan Oliva, bahwa Kurikulum merupakan produk dari waktu, menyembuhkan dan menanggapi diubah oleh kekuatan-kekuatan sosial, posisi filsafat, prinsip-prinsip psikologi, kepemimpinan pendidikan pada saat dalam sejarah. Misalanya, jika analisis pengembangan kurikulum pada sekolah kejuruan, maka pengembangan kurikulum harus di dasarkan pada kebutuhan siswa dalam mempersiapkan tenaga kerja. Terkat hal itu Daeng Sudirwo (2002; 5), bahwa "kurikulum SMK haruslah dapat mengantisipasi kebutuhan tenaga kerja, sehingga lulusannya memiliki kemampuan sesuai dengan kebutuhan dunia kerja."

Berkaitan dengan pernyataan tersebut, mengandung makna bahwa kurikulum itu akan dan harus berubah (adanya pengembangan) sejalan dengan perubahan yang terjadi dalam setiap bidang kehidupan. Dasar pengembangan kurikulum adalah untuk mengikuti perubahan sistem sosial, filosofi masyarakat, pandangan terhadap psikologi, dan kebijakan-kebijakan yang terkait dengan pendidikan, serta dalam rangka menjalankan fungsinya kepada masyarakat.

Rancangan analisis kebutuhan melibatkan berbagai pilihan. Pemilihan yang mungkin untuk memberi suatu pandangan menyeluruh tentang kebutuhan siswa dan hal itu dapat menghadirkan minat yang berbeda bila pengambil keputusan dilibatkan. Keputusan harus dibuat atas prosedur yang praktis dengan cara mengumpulkan, mengorganisir, meneliti, dan melaporkan informasi. Adalah penting untuk menyakinkan bahwa analisis kebutuhan tidak menghasilkan suatu beban informasi yang terlalu berat. Analisis kebutuhan perlu untuk suatu alasan yang jelas untuk mengumpulkan berbagai macam informasi yang berbeda agar memastikan bahwa hanya informasi yang akan digunakan benar-benar dikumpulkan.Kurikulum Bahasa Arab Modern merupakan 
rancangan pendidikan yang merangkum semua pengalaman belajar yang disediakan bagi siswa di sekolah. Dalam kurikulum terintegrasi filsafat, nilai-nilai, pengetahuan, dan perbuatan pendidikan. Kurikulum disusun oleh para ahli pendidikan atau ahli kurikulum, ahli bidang ilmu, pendidik, pejabat pendidikan dan lain-lain. Rancangan ini disusun dengan maksud memberi pedoman kepada para pelaksana pendidikan dalam proses pembimbingan perkembangan siswa sendiri, keluarga, maupun masyarakat. ${ }^{7}$

\section{Sejarah Perkembangan Kurikulum Pendidikan Bahasa Arab di Madrasah (1984-2006)}

Kurikulum madrasah perlu dikembangkan secara terpadu, dengan menjadikan ajaran dan nilai-nilai Islam sebagai petunjuk dan sumber konsultasi bagi perkembangan berbagai mata pelajaran. Dalam konteks pendidikan madrasah, maka kurikulum atau program pendidikannya perlu dirancang dan diarahkan untuk membantu, membimbing dan melatih serta mengajar dan atau menciptakan suasana agar para peserta didik dapat mengembangkan dan meningkatkan kualitas. ${ }^{8}$

\section{Perkembangan Kurikulum Bahasa Arab Madrasah Aliyah (MA) 1984}

Pelajaran bahasa Arab merupakan program inti pada kurikulum 1984 di antara dua program yang ada, di samping itu, pelajaran bahasa Arab diberikan mulai mulai kelas I sampai kelas III. Mengingat GBPP MA disesuaikan dengan mata pelajaran umum di SMA pada bidang mata pelajaran umum, maka pelajaran bahasa Arab diajarkan sesuai dengan kebutuhan.Dalam buku kurikulum MA, disebutkan bahwa program pengajaran bahasa Arab di MA berfungsi ganda, sebagai bahasa ilmu pengetahuan dan alat komunikasi. Adapun tujuan yang dijadikan target dalam pengajaran bahasa Arab untuk MA tahun 1984 adalah untuk mengembalikan pengajaran bahasa Arab kepada fungsi komunikasi yaitu murid mampu mengunakan bahasa yang telah dipelajarinya sebagai alat komunikasi. ${ }^{\text {}}$

${ }^{7}$ Nana Syaodia Sukmadinata, Pengembangan Kurikulum Teori Dan Praktek, (Bandung: Remaja Rosdakarya, 1997), 150

8 Ahmadi,Manajemen Kurikulum Pendidikan Kecakapan Hidup, (Yogyakarta: Pustaka Ifada,2013),175-176

${ }^{9}$ Nur Sholeh dan Ulin Nuha, Pengembangan Kurikulum Bahasa Arab, (Yogyakarta: Diva Press, 2003), 77-78 


\section{Perkembangan Kurikulum Bahasa Arab Madrasah Aliyah (MA) Kurikulum 2004 atau Kurikulum Berbasis Kompetensi (KBK}

Bahasa Arab merupakan mata pelajaran yang mengembangkan ketrampilan komunikasi lisan dan tulisan untuk memahami dan mengungkapkan informasi, pikiran, perasaan, serta mengembangkan ilmu pengetahuan umum, dan sosial budaya. Bahasa Arab yang diajarkan di madrasah berfungsi sebagai bahasa agama dan ilmu pengetahuan, di samping alat komunikasi serta alat pengembangan diri peserta didik dalam bidang komunikasi dan ilmu pengetahuan. Dengan demikian mereka dapat tumbuh dan berkembang menjadi warga negara yang cerdas, terampil, serta berkepribadian luhur dan siap mengambil bagian dalam pembangunan nasional.

Rumusan kompetensi dalam KBK merupakan tentang apa yang diharapkan dapat diketahui, disikapi, atau dilakukan oleh sisiwa dalam setiap tingkatan kelas dan sekolah, yang sekaligus yang menggambarkan kemajuan siswa yang dicapai secara bertahap dan berkelanjutan untuk menjadi kompeten. Dengan demikian, dapatlah ditegaskan bahwa KBK memiliki ciri-ciri: menekankan pada ketercapaian pada kompetensi siswa, baik secara individual maupun klasikal; berorientasi pada hasil belajar dan keberagaman; penyampaian pembelajaran dengan menggunakan pendekatan dan metode yang bervariasi; sumber belajar bukan hanya guru, tetapi juga sumber belajar lainya yang memenuhi unsur edukatif; dan penilaian penekanan pada proses dan hasil belajar dalam upaya dalam penguasaan atau pencapaian suatu kompetensi. ${ }^{10} \mathrm{KBK}$ yang dikembangkan Depdiknas merupakan kerangka inti yang memiliki empat kompenen: Kurikulum dan Hasil Belajar,Penilaian Berbasis Kelas, Kegiatan Belajar Mengajar, Pengelolaan Kurikulum Berbasis Sekolah. Keempat kompenen KBK ini merupakan satu kesatuan yang utuh karena dalam praktiknya kompenen-kompenen ini saling menunjang. ${ }^{11}$

\section{Perkembangan Kurikulum Bahasa Arab Madrasah Aliyah (MA) Kurikulum 2006 atau Kurikukum Tingkat Satuan Pendidikan (KTSP)}

Mata pelajaran bahasa Arab merupakan suatu mata pelajaran yang diarahkan untuk mendorong, membimbing, mengembangkan dan membina kemampuan serta menumbuhkan sikap positif terhadap bahasa Arab, baik reseptif maupun produktif. Kemampuan reseptif yaitu kemampuan untuk memahami pembicaraan orang lain dan memahami bacaan. Kemampuan produktif yaitu kemampuan menggunankan bahasa sebagai alat komunikasi baik

\footnotetext{
10 Ibid.,h.123-125

${ }^{11}$ Masnur Muslich, KTSP Pembelajaran Berbasis Kompetensi dan Kontekstual, Jakarta: Bumi Aksara, 2009), 23
} 
secara lisan maupun tulisan. Kemampuan berbahasa Arab serta sikap positif terhadap bahasa Arab tersebut sangat penting dalam membantu memahami sumber ajaran Islam, yaitu Al-Qur'an dan Hadist, serta kitab-kitab berbahasa Arab yang berkenan dengan Islam bagi peserta didik.

Untuk itu, bahasa Arab di MA dipersiapkan untuk pencapaian kompetensi dasar berbahasa yang mencakup empat ketrampilan berbahasa yang diajarkan secara integral, yaitu menyimak, berbicara, membaca dan menulis. Dengan kata lain, pada tingkat pendidikan menengah (intermidiate), keempat kecakapan berbahasa diajarkan secara seimbang pada tingkat pendidikan lanjut (advanced) dikonsentrasikan pada kecakapan membaca dan menulis, sehingga peserta didik mampu mengakses berbagai reverensi bahasa Arab.

Titik fokus perkembangkan bahasa Arab pada kurikulum KTSP adalah sebagaimana telah diuraikan pada bagian sebelumnya, gimana kurukulum bahasa Arab tersebut memberikan penekanan pada implementasi pada kehidupan dengan mempertimbangkan kearifan lokal dan perkempangan IPTEK. Mengingat penyusunan KTSP diserahkan kepada satuan pendidikan, maka dapat diasumsikan bahwa guru, kepala madrasah, dan komite madrasah harus bekerja sama secara sinergis, karena mereka terlibat secara langsung dalam proses penyusunannya.

\section{Perubahan-Perubahan Kurikulum Pengembangan Bahasa Arab}

KBK merupakan seperangkat rencana dan pengaturan tentang kompetensi dan hasil belajar, serta pemberdayaan sumber daya pendidikan. Bahasan tersebut menyiratkan bahwa KBK dikembangkan dengan tujuan agar peserta didik memperoleh kompetensi dan kecerdasan yang mumpuni dalam membangun identitas budaya dan bangsanya. Melalui penerapan KBK tamatan diharapkan memiliki kompetensi atau kemampuan akademik yang baik, ketrampilan untuk menunjang hidup yang memadai, pengembangan moral yang terpuji, pembentukan karakter yang kuat, kebiasaan hidup yang sehat, bekerja sama yang kompak, dan apresiasi estetika yang tinggi terhadap dunia sekitar. Berbagai kompetensi tersebut harus berkembang secara harmonis dan berimbang. Sementara itu, Kurikulum Tingkat Satuan Pendidikan (KTSP) yang merupakan penyempurnaan dari kurikulum 2004 (KBK) adalah kurikulum operasional yang disusun dan dilaksanakan oleh masing-masing satuan pendidikan atau sekolah. ${ }^{12}$

Dengan berkembangnya kurikulum untuk menghadapi sesuai tantangan zaman maka perlu adanya perubahan-perubahan dan pengembangan kurikulum

${ }^{12}$ Masnur Muslich, KTSP Pembelajaran Berbasis Kompetensi dan Kontekstual,17 
untuk memiliki visi dan arah yang jelas yaitu perubahan kurikulum 2013. Begitupun dengan kurikulum bahasa Arab Sejak perubahan dan pengembangan kurikulum 2013 telah muncul berbagai tanggapan dari berbagai kalangan, baik yang pro maupun yang kontra. Mendikbud mengungkapkan bahwa perubahan dan pengembangan kurikulum merupakan persoalan yang sangat penting, karena kurikulum harus senantiasa disesuaikan dengan tuntutan zaman. Perlunya perubahan dan pengembangan kurikulum 2013 didorong oleh beberapa hasil studi internasional tentang kemampuan peserta didik Indonesia dalam kancah internasional. Perlunya perubahan kurikulum juga karena adanya beberapa kelemahan yang ditemukan dalam KTSP 2006 antara lain: Isi dan pesan kurikulum masih terlalu padat, kurukulum belum mengembangkan kompetensi secara utuh sesuai dengan visi, misi, dan tujuan pendidikan nasional, kurikulum belum peka dan tanggap terhadap berbagai perubahan sosial yang terjadi pada tingkat lokal, nasional, maupun global, Standar pembelajaran belum mengambarkan urutan pelajaran yang rinci, penilaian belum menggunakan standar penilaian berbasis kompetensi, serta belum tegas memberikan layanan remediasi dan pengayaan secara berkala. ${ }^{13}$

\section{Konsep dasar dalam pengembangan kurikulum bahasa arab}

Konsep kurikulum berkembang sejalan dengan perkembangan teori dan praktik pendidikan,jugabervariasi sesuai dengan aliran tau teori pendidikan yang dianut.Menurut pandangan lama,kurikulum merupakan kumpulan mata mata pelajaran yang harus di sampaikan guru atau di pelajari oleh siswa anggapan ini telah ada sejak zaman yunani kuno, dalam lingkungan atau hubungan tertentu pandangan ini masih dipakai sampai sekarang,yaitu kuri kulum sebagai "..., a racecaurse of subject matters to be mastered', banyak orang tua dan guru kalau ditanya tentang kurikulum akan memberikan jawaban sekitar bidang studi atau mata pelajaran lebih khusus mungkin kurikulum diartikan hanya sebagai isi pelajaran

Pendapat pendapat yang muncul selajutnya telah beralih dari menekan pada isi menjadi lebih memberikan tekanan pada pengalaman belajar. Menurut Caswel dan Campbell dalam buku mereka yang terkenal Curriculum develoment, kurikulum to be composed of all the experences children have under the guidance of teacher perubahan penekanan pada pengalman ini lebih jelas di tegaskan oleh Ronald C.doll definisi doll tidak hanya menujukan adanya perubahan penekanan dari isi kepada proses.

Maurit johnson $(1967$, hlm,130) mengajukan keberatan terhadap konsep kurikulum yang sangat luas seperti yang di kemukakan oleh Ronald

13 Mulyasa, Pengembangan dan Implementasi Kurikulum 2013, (Bandung: Remaja Rosdakarya, 2015), 59-61 
Doll.Menurut johnson,pengalaman hanya akan muncul apa bila interaksi antara siswa dengan lingkunganya,interaksi seperti itu bukan kurikulum,tetapi pengajaran kurikulum hanya menggambarkan atau mengantisi pasi hasil pembelajaran jihnson membedakan dengan tegas antara kurikulum dan pengajaran semua yang berkenaan dengan perencanaan isi,kegiatan belajar mengajar,evaluasi,termasuk pengajaran,sedangkan kurikulum hanya berkenaan dengan hasil hasil belajar yang di harapkan di capai oleh siswa.

Terlepas dari pro dan kontra terhadap pendapat Mauritz johnson, beberapa ahli memandang kurikulum sebagi rencana pendidikan atau pengajaran salah seorang dari mereka adalah Mac donald $(1965, \mathrm{hlm}, 3)$ menurut dia,sistem persekolahan terbentuk atas empat subsistem yaitu mengajar,belajar,pembelajaran, Kurikulum juga sering di bedakan antara kurikulum sebai rencana (curikulum pIan) dengan kurikulm fungsional (fungtioning curriculum).

Hilda Taba mempunyai pendapat yang berbeda dengan pendapat pendapat itu perbedaan antara kurikulum dan pengajaran menurut dia bukan terletak pada implementasinya, tetapi pada keluasan cakupanya kurikulum berkenan dengan cakupan tujuan isi dan metode yang lebih luas atau lebih umum,sedangkan yang kebih sempit lebih khusus menjadi tugas pegajaran.Menurut Taba keduanya membentuk satu kontinum,kurikulum terletak pada ujung tujuan umum atau tujuan jangka panjang,sedangkan pengajaran pada ujung lainya yaitu yang lebih khusus atau tujuan dekat.

\section{Konsep Pembelajaran Bahasa Arab Berbasis Kurikulum 2013}

Kurikulum 2013 merupakan tindak lanjut dari kurikulum berbasis kompetensi (KBK) yang prnah diujicobakan pada tahun 2004. KBK dijadikan sebagai acuan dan pedoman bagi pelaksanaan pendidikan untuk mengembangkan brbagai ranah pendidikan (pengetahuan, ketrampilan dan sikap) dalam seluruh jenjang dan jalur pendidikan, khususnya pada jalur pendidikan sekolah.

Pada hakikatnya kompetensi merupakan perpaduan dari pengetahuan, ketrampilan, nilai dan sikap yang direfleksikan dalam kebiasaan berpikir dan bertindak. Hal trsebut menunjukkan bahwa kompetensi mencakup tugas, ketrampilan, sikap dan apresiasi yang harus dimiliki oleh peserta didik untuk melaksanakan tugas-tugas pembelajaran sesuai dengan jenis pekerjaan tertentu. Beberapa aspek atau ranah yang terkandung dalam konsep kompetensi dapat diuraikan sbagai berikut :

1. Pengetahuan (knowledge); yaitu kesadaran dalam bidang kognitif. 
2. Pemahaman (understanding); yaitu kedalaman kognitif peserta didik, dan afektif yang dimiliki oleh individu.

3. Kemampuan (skill); adalah sesuatu yang dimiliki oleh individu untuk melakukan tugas atau pekerjaan yang dibebankan kepadanya.

4. Nilai (value); yaitu suatu standar perilaku yang telah diyakini dan secara psikologis telah menyatu dalam diri seseorang.

5. Sikap (attitude); yaitu perasaan (senang-tidak senang, suka-tidak suka) atau reaksi terhadap suatu rangsangan yang datang dari luar.

6. Minat (interest); kecenderungan sseorang untuk melakukan sesuatu perbuatan.

Berdasarkan analisis kompetensi di atas, Kurikulum 2013 berbasis kompetensi dapat dimaknai sebagai suatu konsep kurikulum yang menekankan pada pengembangan kemampuan melakukan (kompetensi) tugas-tugas dengan standar performansi tertentu, sehingga hasilnya dapat dirasakan oleh peserta didik, berupa penguasaan terhadap seprangkat kompetensi tertentu. Kurikulum ini diarahkan untuk mengembangkan pengetahuan, pemahaman, kemampuan, nilai sikap, dan minat peserta didik, agar dapat melakukan sesuatu dalam bentuk kemahiran, ketepatan, dan keberhasilan dengan penuh tanggung jawab. ${ }^{14}$

Lahirnya kurikulum 2013 ini untuk menjawab tantangan dan pergeseran paradigma pembangunan dari abad ke-20 menuju abad ke-21. Adapun pergesesaran paradigma pembangunan dari abad ke-20 menuju abad ke- 21 dapat dilihat dalam tabel berikut ini :

\begin{tabular}{|c|c|c|}
\hline No. & Abad ke-20 & Abad ke-21 \\
\hline 1. & $\begin{array}{l}\text { Pembangunan konomi berbasis } \\
\text { sumber daya }\end{array}$ & $\begin{array}{ll}\text { Pembangunan } & \text { kesejahteraan } \\
\text { berbasis peradaban } & \end{array}$ \\
\hline 2. & $\begin{array}{l}\text { Sumber daya alam sebagai modal } \\
\text { pembangunan }\end{array}$ & $\begin{array}{lll}\text { Peradaban } & \text { sebagai } & \text { modal } \\
\text { pembangunan } & & \end{array}$ \\
\hline 3. & $\begin{array}{l}\text { Sumber Daya Manusia sebagai } \\
\text { Beban Pembangunan }\end{array}$ & $\begin{array}{l}\text { SDM Beradab sebagai modal } \\
\text { pembangunan }\end{array}$ \\
\hline 4. & $\begin{array}{l}\text { Penduduk } \quad \text { sebagai } \\
\text { pengguna }\end{array}$ & $\begin{array}{l}\text { Penduduk } \\
\text { pelaku/produsen }\end{array}$ \\
\hline 5. & Kekayaan Alam & Kekayaan Pearadaban \\
\hline
\end{tabular}

Sumber: Kemendikbud, 2013

Pemerintah berasumsi bahwa pengembangan kurikulum mutlak diperlukan untuk menjawab tantangan masa depan yang dihadapi bangsa

${ }^{14}$ E. Mulyasa, Pengembanagn dan Implementasi Kurikulum 2013, (Bandung: PT Remaja Rosdakarya, 2013) hlm. 66-68 
Indonesia. ${ }^{15}$ Sebagaimana yang dikatakan Mendikbud bahwa perubahan dan pengembangan kurikulum merupakan persoalan yang sangat penting, karena kurikulum harus senantiasa disesuaikan dengan tuntutan zaman. ${ }^{16}$ Kurikulum 2013 bertujuan untuk mempersiapkan manusia Indonesia agar memiliki kemampuan hidup sebagai pribadi dan warga negara yang beriman, produktif, kreatif, inovatif, dan afektif serta mampu berkontribusi pada kehidupan bermasyarakat, berbangsa, bernegara, dan peradaban dunia.

\section{Need Analysis dalam pengembangan kurikulum bahasa arab}

Analisa atau analisis dalam kajian linguistik diartikan dengan sebuah kajian yang dilaksanakan terhadap sebuah bahasa guna meneliti struktur bahasa tersebut secara mendalam. Analisis juga diartikan dengan penyelidikan terhadap suatu peristiwa baik berupa karangan atau sebuah perbuatan untuk mengetahui keadaan yang sebenarnya dari segi sebab-musabab maupun duduk perkaranya. ${ }^{17}$

Kebutuhan dapat diartikan dengan sesuatu yang dibutuhkan. ${ }^{18}$ Atau sebuah kesenjangan antara apa yang ada dan apa yang seyogyanya ada. Sedangkan kebutuhan bagi seorang pendidik adalah : sesuatu yang digunakan untuk menentukan latar belakang atas konsep keanekaragaman yang tidak terbatas, guna menyeleksi bidang-bidang normatif19 yang mengandung kekurangan untuk disediakan penyesuaiannya oleh pendidik. ${ }^{20}$

Kebutuhan sebagai sesuatu yang urgen dalam perencanaan kurikulum, berkaitan erat dengan pengembangan kurikulum dan pembelajaran. Kebutuhan dalam konsep ini didefinisikan sebagai actual circumstance (keadaan aktual/keadaan yang sedang diperbincangkan) dan envisional ideal circumtance (keadaan ideal yang dicita-citakan). Atau dengan kata lain, suatu perbedaan antara keadaan riil dan kondisi ideal. ${ }^{21}$

Kurikulum adalah : Segala pengalaman pendidikan yang diberikan oleh sekolah kepada seluruh anak didiknya, baik dilakukan didalam maupun diluar sekolah. Pengalaman anak didik disekolah diperoleh melalui : mengikuti

15 Kunandar, Penilaian Autentik: Penilaian Hasil Belajar Peserta Didik Berdasarkan Kurikulum 2013, (Jakarta: PT RajaGrafindo Persada, 2014) hlm. 16

${ }^{16}$ E. Mulyasa, Pengembanagn dan Implementasi Kurikulum 2013,,, hlm. 60

17 Tim Redaksi Kamus Besar Bahasa Indonesia Edisi Ketiga, Kamus Besar Bahasa Indonesia Edisi Ketiga, (Jakarta : Balai Pustaka, 2005), 43.

18 Ibid.,182.

19 Normatif menurut kamus besar Bahasa Indonesia adalah : Berpegang teguh pada norma atau menurut pada kaidah yang berlaku.

${ }^{20}$ Hendri Guntur Taringan, Dasar-dasar Kurikulum Babasa, 80.

21 Oemar Hamalik, Dasar-dasar Pengembangan Kurikulum, (Bandung : PT Remaja Rosdakarya, 2008, cet. ke-2), 188-189. 
pelajaran dikelas, praktek keterampilan, latihan-latihan olahraga dan kesenian, karya wisata atau praktek di laboratorium. Menurut pandangan tradisional, kurikulum adalah : rencana pendidikan dan pengajaran atau program pendidikan. Karena kurikulum terdiri atas mata pelajaran tertentu yang harus diajarkan kepada siswa-i yang diambil dari buku-buku pelajaran tertentu yang dipandang baik. $^{22}$

Sehingga tujuan dari analisis kebutuhan dalam pengembangan kurikulum bahasa adalah :

1. Menyediakan mekanisme pemerolehan gagasan yang lebih luas dan menyeluruh tentang isi, rancang bangun dan implementasi program/kurikulum bahasa arab.

2. Mengenali kebutuhan bahasa umum dan khusus yang bermanfaat bagi pengembangan maksud, tujuan, dan isi bagi program bahasa arab.

3. Menyediakan data yang berguna bagi peninjauan ulang dan peninjauan program bahasa yang ada.

Analisis kebutuhan kurikulum bahasa arab dapat mengacu para beberapa parameter atau ukuran yang meliputi : Analisis situasi (analisi yang terfokus pada parameter umum program bahasa arab) dan Analisis kebutuhan komunikatif (analisis yang terfokus pada kebutuhan komunikatif atau kemudahan pemahaman terhadap bahasa arab, khususnya bagi para pembelajar bahasa arab). Cakupan analisis kebutuhan kurikulum dalam program bahasa arab meliputi :

1. Analisis Situasi

a. Siapakah pembelajar bahasa arab tersebut?

b. Apa tujuan dan harapan pembelajar?

c. Gaya belajar apa yang lebih disukai pembelajar?

d. Mahirkah pengajar bahasa arab tersebut?

e. Siapa pengajar bahasa arab tersebut?

f. Pelatihan dan pengalaman apakah yang dimilliki pengajar?

g. Pendekatan mengajar apa yang disenangi pengajar?

h. Apakah yang diharapkan pengajar dari program pengajaran bahasa tersebut?

i. Apakah konteks administratif program itu? $32-33$.

${ }^{22}$ Suryosubroto, Manajemen Pendidikan Di Sekolah, (Jakarta : PT. Rineka Cipta, 2004), 
j. Kendala apakah yang muncul dalam pembelajaran?

k. Tes dan penilaian apa yang diperlukan?

2. Analisis kebutuhan komunikatif

a. Dalam latar belakang apa pembelajar memakai bahasa tersebut?

b. Hubungan peran apa yang terlibatkan?

c. Keterampilan bahasa apa yang dilibatkan?

d. Peristiwa komunikatif dan tindak tutur apa yang dilibatkan?

e. Tingkat kemahiran apa yang dikehendaki?

\section{Metode Analisa Kebutuhan Sebagai Konsep Dasar dalam Pengembangan Kurikulum Bahasa Arab di MAN Curup}

Metode sebagai suatu rencana yang menyeluruh yang berhubungan dengan penyajian materi secara teratur dan tidak saling bertentangan dan didasarkan atas suatu approach. Diamana approach bersifat axiomatic, sedangkan metode bersifat proseduril. Maka dalam suatu approach bisa saja terdapat berbagai macam metode, khususnya dalam suatu pembelajaran. Adapun yang dimaksud dengan metode dalam penelitian ini adalah cara yang digunakan untuk mengungkap atau menganalisa sebuah data atau permasalahan agar dapat mengungkap berbagai fakta yang ada dalam data tersebut. Dalam hal ini para peneliti menggunakan pendekatan kualitatif deskriptif melalui interview atau wawancara objek yang diteliti, yaitu guru bahasa Arab di MAN Curup. Adapun metode yang digunakan adalah pendekatan eksploratif, untuk menemukan jawaban yang tepat dari masalah yang diteliti. Adapun teknik yang dilakukan random sampling dengan skala riket atau acak. Ini dilakukan berdasarkan tingkat kemapuan dan latar belakang pendidikan mahasiswa, sehingga lebih memudahkan peneliti dalam mengungkap berbagai persoalan yang dialami oleh guru bahasa Arab dalam proses pengajaran bahasa Arab

Adapun populasi dalam penelitian ini adalah guru bahasa Arab di Man Curup. Dengan sampel adalah sebagain dari populasi. Sampel yang baik adalah sampel yang mewakili populasi dan sekaligus menggambarkan populasi itu sendiri. Suharsimi Arikunto, berpendapat bahwa apabila subjeknya kurang dari 100, lebih baik diambil semua sehingga penelitiannya merupakan penelitian populasi. Selanjutnya jika subjeknya besar maka dapat diambil antara 10\%-15\% atau 20\%-25\% atau lebih. ${ }^{23}$ Dengan mengunakan data yang dihimpun dalam

${ }^{23}$ SuharsimiArikunto, ProsedurPenelitian: SuatuPendekatanPraktek, hlm. 102 
penelitian ini adalah data kualitatif tentang analisis kebutuhan kurikulum pembelajaran bahasa Arab. Dengan sumber data yang digunakan dalam penelitian ini ada dua macam, yaitu data primer dan data skunder. Data primer adalah sumber data yang dikumpulkan langsung dari tangan pertama, yaitu guru bahasa Arab di MAN Curup. Sedangkan data skunder adalah sumber data pendukung yang berupa bahan-bahan perpustakaan yang berkenaan langsung dengan analisis kurikulum pembelajaran bahasa Arab

Mengingat penelitian ini memakai pendekatan kualitatif, maka data akan dikelompokkan dalam beberapa bagian yang saling menyatu tentang data-data hasil angket, wawancara dan dokumentasi. Kemudian data yang diperoleh dianalisa secara cermat dan teliti, sebagai upaya untuk mendapatkan data yang benar-benar objektif. Maka dalam menentukan instrumen sangat memperhitungkan berbagai aspek yang terkait guna untuk mendapatkan datadata yang lebih akurat dan benar. Selanjutnya data-data yang telah dikelompokkan dianalisa satu persatu dan diberi makna dan dijabarkan sesuai dengan makna yang diperoleh. Dalam analisa data-data tersebut dilakukan dengan sangat cermat agar tidak terjadi kesalahan dan kekeliruan dalam mempersepsikannya.

\section{Metode Pembelajaran Bahasa Arab}

Metode (al thariqab) adalah langkah-langkah umum tentang penerapan teori-teori yang ada pada pendekatan tertentu. ${ }^{24}$ Menurut Azhar Arsyad, metode adalah rencana menyeluruh yang berkenaan dengan penyajian materi bahasa secara teratur, tidak ada satu bagian yang bertentangan dengan yang lain dan semuanya berdasarkan atas approach yang telah dipilih. ${ }^{25}$ Selain itu metode dapat didefinisikan sebagai seperangkat cara yang digunakan oleh guru dalam menyampaikan ilmu atau transfer ilmu kepada anakdidiknya yang berlangsung dalam proses belajar dan mengajar atau proses pembelajaran. ${ }^{26}$ Adapun metode pembelajaran adalah suatu model dan cara yang dapat dilakukan untuk menggelar aktivitas belajar-mengajar agar berjalan dengan baik. ${ }^{27}$ Macam-macam Metode Pembelajaran Bahasa arab

24 Acep Hermawan, Metodologi Pembelajaran Bahasa Arab, (Bandung: PT Remaja Rosdakarya, 2011) hlm. 168

${ }^{25}$ Azhar Arsyad, Bahasa Arab dan Metode Pengajarannya, (Pustaka Pelajar: Yogyakarta, 2010) hlm,19

${ }^{26}$ Ulin Nuha, Metodologi Super Efektif Pembelajaran Bahasa Arab, Jogjakarta:DIVA Press, 2012) hlm.157

${ }^{27}$ Heri Rahyubi, Teori-teori Belajar dan Aplikasi Pembelajaran Motorik, (Bandung: Nusa Media, 2012) hlm.236 
Dikarenakan metode merupakan rencana terkait penyajian materi maka ada berbagai metode dalam pembelajaran bahasa Arab, diantaranya: Beberapa metode yang cukup besar pengaruhnya dalam dunia pembelajaran bahasa Arab, diantaranya :

\section{Metode Gramatika-Terjemah}

Adalah metode yang berasumsikan bahwa semua bahasa di dunia dasarnya sama, dan tata bahasa adalah cabang dari logika. Metode ini didasari oleh pendekatan teori tradisional. Teori ini melihat bahasa secara preskriptif, artinya bahasa yang baik dan benar adalah menurut para ahli bahasa, bukan yang digunakan oleh penutur asli di lapangan. Sehingga metode kaidah dan terjemah melihat bahasa secara preskriptif, dengan demikian kebenaran bahasa brpedoman pada petunjuk tertulis, yaitu aturan-aturan gramatikal yang ditulis oleh ahli bahasa, bukan menurut ukuran guru.

2. Metode Langsung

Metode ini berasumsi bahwa belajar bahasa asing sama dengan belajar bahasa ibu, yakni penggunaan bahasa secara langsung dan intensif dalam komunikasi. ${ }^{28}$ Selain itu, metode ini juga didasarkan atas asumsi yang brsumber dari hasil-hasil kajian psikologi asosiatif. Berdasarkan kedua asumsi tersebut, pengajaran bahasa khususnya pengajaran kata dan kalimat harus dihubungkan langsung dengan benda, sampl atau gambarnya, atau melalui peragaan, permainan peran dan lain sebagainya. ${ }^{29}$ Metode ini mempunyai tujuan agar para pelajar mampu berkomunikasi dengan bahasa asing yang dipelajarinya seperti pemilik bahasa ini.metode ini dinamakan metode langsung, sebab guru langsung menggunakan bahasa asing (bahasa Arab) yang sedang diajarkan selama pelajaran, sedangkan bahasa murid tidak boleh digunakannya. ${ }^{30}$

3. Metode Audiolingual

Metode ini mendasarkan diri kepada pendekatan struktual dalam pengajaran bahasa. Metode ini berasumsi bahwa bahasa itu pertama-tama adalah ujaran dan bahasa itu kebiasaan. Sebagai implikasinya metode ini menekankan penelaahan dan pendeskripsian suatu bahasa yang akan dipelajari dengan memulainya dari sisitem bunyi (fonologi), kemudian system pembentukan kata ( morfologi), dan system pembentukan kalimat (sintaksis). Maka bahasa tujuan

28 Acep Hermawan, Metodologi Pembelajaran Bahasa Arab, (Bandung: PT Remaja Rosdakarya, 2011) hlm.176-177

${ }^{29}$ Ahmad Fuad Effendy, Metodologi Pembelajaran Bahasa Arab, ( Malang: Misykat, 2012 ) hlm. 47

${ }^{30}$ Wa Muna, Metodologi Pembelajaran Bahasa Arab: Teori dan Aplikasi, (Yogyakarta: Teras, 2011) hlm. 85 
diajarkan dengan mencurahkan perhatian lafal kata, dan pada latihan berkali-kali (drill) secara intensif. Bahakan drill inilah yang biasanya dijadikan teknik utama dalam proses belajar mengajar. ${ }^{31}$ Teori structural bersifat deskriptif yang berpandangan bahwa bahasa yang baik dan benar adalah yang digunakan oleh penutur asli dan bukan apa yang dikatakan oleh ahli tata bahasa. ${ }^{32}$

4. Metode Komunikatif

Metode komunikatif memiliki landasan toritis yang kuat yaitu hakekat dan fungsi bahasa sebagai alat komunikasi dan interaksi social. Metode ini juga didasarkan atas asumsi bahwa setiap manusi memiliki kemampuan bawaan yang disebut dengan "pemerolehan bahasa" (language acquisition device). Oleh karena itu kemampuan berbahasa bersifat kreatif dan lebih ditentukan oleh factor internal. Dengan demikian, relevansi dan efektivitas kegiatan pembiasaan dengan model latihan stimulus-response-inforcment dipersoalkan. Dalam proses belajar mengajar, siswa bertindak sebagai komunikator yang berperan aktif dalam aktivitas komunikatif yang sesungguhnya. ${ }^{33}$

\section{Penggunaan Media dalam Pembelajaran Bahasa Arab}

Kata media berasal dari kata Latin "medius" yang artinya "tengah". 34 Secara umum, media adalah semua bentuk perantara untuk menyebar, membawa atau menyampaikan sesuatu pesan (message) dan gagasan kepada penerima. Media adalah segala sesuatu yang dapat dipergunakan untuk menyalurkan pesan dan dapat merangsang pikiran, dapat membangkitkan semangat, perhatian, dan kemauan pelajar sehingga dapat mendorong terjadinya proses pembelajaran pada diri pelajar. Pendek kata media pembelajaran adalah segala sesuatu yang digunakan untuk mempermudah penyampaian materi pembelajaran. ${ }^{35}$

Proses pembelajaran adalah kegiatan komunikasi yang melibatkan banayak unsur. Penggunaan media dalam pengajaran bahasa brtitik tolak dari teori yang mengatakan bahwa totalitas persntase banyaknya ilmu pengetahuan, ketrampilan, dan sikap yang dimiliki oleh seseorang terbanyak dan tertinggi melalui indra lihat dan pengalaman langsung melakukan sendiri, sedangkan selebihnya melalui indra dengar dan indra lainnya. Lebih lanjut Mudjiono dkk (1980:2-3) menambahkan bahwa media pembelajaran dapat membangkitkan motivasi belajar serta memberikan stimulus bagi kemauan belajar. Dengan demikian, apapun materi pembelajarannya, khusussnya bahasa Arab,

\footnotetext{
${ }^{31}$ Acep Hermawan, Metodologi Pembelajaran Bahasa Arab,,, hlm. 185.

${ }^{32}$ Ahmad Fuad Effendy, Metodologi Pembelajaran Bahasa Arab,,, hlm. 60

33 Ibid.,h.67-68

${ }^{34}$ Azhar Arsyad, Bahasa Arab dan Metode Pengajarannya, hlm. 74

${ }^{35}$ Acep Hermawan, Metodologi Pembelajaran Bahasa Arab,,, hlm. 223- 224
} 
penggunaan media itu penting sekali, karena membuat proses pembelajaran akan semakin mudah bermakna bagi para pelajar. ${ }^{36}$

Secara garis besar, media pembelajaran bahasa Arab dapat dibagi menjadi tiga, yaitu :

1. Media Audio (Al-wasail al-sam'iyyah)

Media audio adalah segala sesuatu yang dapat dimanfaatkan untuk memudahkan pembelajaran bahasa yang dapat ditangkap dan dierna melalui indra penglihatan. Misalnya, bahasa. Tape recoerder, radio transistor, televise, laboratorium bahasa, dan sebagainya.

2. Media visual (Al-wasail al-bashariyyah)

Media visual adalah segala sesuatu yang dapat dimanfaatkan untuk memudahkan proses pembelajaran bahasa yang dapat ditangkap dan dicerna oleh indra penglihatan. Misalnya benda asli, benda tiruan, gambar, papan tulis dan sebagainya.

3. Media audio-visual (Al-wasail al-sam’iyyah al-bashariyyah)

Adalah segala sesuatu yang dapat dimanfaatkan untuk memudahkan pembelajaran bahasa yang ditangkap dan dicerna melalui indra pendegaran dan penglihatan. Misalnya telvisi, video $\mathrm{CD}$, film, laboratorium bahasa dan lain sebagainya. ${ }^{37}$

Ketiga jenis media tersebut dapat dipergunakan dalam proses pembelajaran bahasa Arab. Media tersebut menjadi factor pendukung keberhailan pembelajaran bahasa Arab. Aplikasi dari tiap-tiap media tersebut dengan menyesuaikan aspek kebahasaan bahasa Arab yakni empat ketrampilan bahasa Arab sangat membantu pemahaman dalam pembelajaran bahasa Arab.

Mengenai penilaian, salah satu penekanan dalam kurikulum 2013 adalah penilaian autentik (authentic assessment). Penilaian autentik adalah kegiatan menilai peserta didik yang menekankan pada apa yang seharusnya dinilai, baik proses maupun hasil dengan berbagai instrument penilaian yang disesuaikan adengan tuntutan kompetensi yang ada di Standar Kompetensi (SK) atau kompetensi Inti (KI) dsn Kompetensi Dasar (KD). Dalam kurikulum 2013 mempertegas adanya pergeseran dalam melakukan penilaian, yakni dari penilaian melalui tes (mengukur kompetensi pengetahuan berdasarkan hasil saja), menuju penilaian autentik (mengukur kompetensi sikap, ketrampilan, dan pengetahuan berdasarkan proses dan hasil).

\footnotetext{
${ }^{36}$ Ibid.,h.223-224

${ }^{37}$ Ibid.,h.227
} 


\section{Kesimpulan}

Seiring analisis kebutuhan kurikulum merupakan suatu proses formal untuk menentukan jarak atau kesenjangan antara seperti apa yang ada dan bagaimana seharusnya dari suatu kurikulum, diambil prioritas masalah utamanya lalu diselesaikan masalahnya. Analisis kebutuhan adalah alat yang konstruktif dan positif untuk melakukan perubahan yang didasarkan atas logika yang bersifat rasional, perubahan yang bersifat fungsional yang dapat memenuhi kebutuhan warga negara, kelompok dan individu.

Karena kurikulum adalah bagian dari pendidikan, maka tujuan kurikulum hanya untuk kepentingan tujuan pendidikan. Adapun tujuan dari analisis kebutuhan kurikulum adalah untuk mencari solusi yang tepat untuk memecahkan masalah kurikulum. Salah satu asumsi dasar pengembangan kurikulum dalam bidang pendidikan harus didasarkan pada analisis kebutuhan siswa. Prosedur yang digunakan untuk mengumpulkan informasi tentang kebutuhan siswa dikenal dengan analisis kebutuhan. Metode analisis kebutuhan dalam pengembangan kurikulum dibuat untuk bisa mengukur tingkat kesenjangan yang terjadi dalam pembelajaran siswa dari apa yang diharapkan dan apa yang sudah didapat. Dalam pengukuran kesenjangan seorang analisis harus mampu mengetahui seberapa besarmasalah yang dihadapi.

Dapat disimpulkan bahwa perlu diterapkan need analyisis dalam pembelajaran bahasa arab, dengan demikian membantu para pendidik dan peserta didik dalam menerapkan metode, materi dalam proses pembelajaran. Serta kurikulum merupakan syarat mutlak bagi pendidikan di sekolah, hal ini berarti kurikulum merupakan bagian yang tidak terpisahkan dari pendidikan atau pengajaran. Kurikulum mempunyai kedudukan sentral dalam sebuah proses pendidikan. Kurikulum mengarahkan segala bentuk aktifitas pendidikan demi tercapainya tujuan tujuan pendidikan. Kurikulum juga merupakan suatu rencana pendidikan, memberikan pedoman dan pegangan tentang jenis, lingkup dan urutan isi, serta proses pendidikan. Di samping kedua fungsi itu, kurikulum juga merupakan suatu bidang studi yang ditekuni oleh para ahli atau spesialis kurikulum yang menjadi sumber konsep-konsep atau memberikan landasanlandasan teoritis bagi pengembangan kurikulum berbagai institusi pendidikan.Kurikulum merupakan keseluruhan rencana dan aktifitas yang diselenggarakan dan diorganisasi oleh sekolah baik di dalam kelas maupun di luar kelas dalam rangka mencapi tujuan pendidikan yang diinginkan.

Salah satu kelemahan mendasar sistem pengajaran bahasa Arab adalah lemahnya kurikulum pengajaran yang diterapkan. Dalam segala bentuk dan aspeknya, terutama visi dan metodologi dan pengajarannya, kurikulum yang pada umumnya mengajarkan bahasa Arab dengan menggunakan orientasi secara 
tradisional atau sorogan, yaitu untuk memenuhi tujuan-tujuan keagamaan. Pada masa sekarang ini, sistem pengajaran dengan orientasi tradisional tidaklah relevan, oleh karena itu harus mempunyai perubahan. Bahasa Arab sebagai bahasa internasional tidak lagi hanya berfungsi sebagai bahasa Agama akan tetapi sebagai bahasa komunikasi dan pengetahuan.Bahasa Arab tidak hanya dikuasai secara pasif tetapi dikuasai secara komunikatif dalam pengertian yang lebih luas, baik secara lisan maupun tulisan. Maka dari itu, pengembangan kurikulum yang mendukung sistem pengajaran bahasa Arab yang lebih modern menjadi sebuah keharusan. Kurikulum pada pembelajaran bahasa Arab modern harus lebih fokus pada praktek dengan mengembleng agar mampu menguasai empat ketrampilan bahasa Arab, yaitu ketrampilan mendengar, berbicara, membaca dan menulis, untuk bersaing dalam ilmu pengetahuan di masa yang akan datang.

Kurikulum terus mengalami perubahan. Perubahan tersebut terus berkembang untuk memiliki visi dan arah yang jelas, karena muncul berbagai tanggapan dari berbagai kalangan, baik yang pro maupun yang kontra. Mendikbud mengungkapkan bahwa perubahan dan pengembangan kurikulum merupakan persoalan yang sangat penting, karena kurikulum harus senantiasa disesuaikan dengan tuntutan zaman

\section{Daftar Pustaka}

Acep Hermawan, Metodologi Pembelajaran Bahasa Arab, Bandung: PT Remaja Rosdakarya, 2011

Arsyad, Azhar, Bahasa Arab dan Metode Pengajarannya, Yogyakarta: Pustaka Pelajar, 20101

Hamalik, Oemar, Sistem dan Prosedur Pengembangan Kurikulum Lembaga Pendidikan dan Pelatihan, Bandung: Trigenda Karya, 1983

Kunandar, Penilaian Autentik: Penilaian Hasil Belajar Peserta Didik Berdasarkan Kurikulum 2013, Jakarta: PT RajaGrafindo Persada, 2014

Hamalik, Oemar, Dasar-dasar Pengembangan Kurikulum, Bandung : PT Remaja Rosdakarya, 2008

Effendy, Ahmad Fuad, Metodologi Pembelajaran Bahasa Arab, Malang: Misykat, 2012

Mulyasa, E., Pengembanagn dan Implementasi Kurikulum 2013, Bandung: PT Remaja Rosdakarya, 2013

Muna, Wa, Metodologi Pembelajaran Bahasa Arab: Teori dan Aplikasi, Yogyakarta: Teras, 2011 
Nuha, Ulin, Metodologi Super Efektif Pembelajaran Bahasa Arab, Yogyakarta: DIVA Press, 2012

Rahyubi, Heri, Teori-teori Belajar dan Aplikasi Pembelajaran Motorik, Bandung: Nusa Media, 2012

Sanjaya, Wina, Pembelajaran dalam Implementasi Berbasis Kompetensi,,(Jakarta: Kencana Media Grup, 2006

Sudjana, Nana, Pembinaan dan Pengembagan Kurikulum di Sekolah, Bandung; Sinar Baru Algensindo, 1988

Sukmadinata, Nana Syaodia, Pengembangan Kurikulum Teori Dan Praktek, Bandung: Remaja Rosdakarya, 1997

Suryosubroto, Manajemen Pendidikan Di Sekolah, Jakarta : PT. Rineka Cipta, 2004

Suryosubroto, Manajemen Pendidikan Di Sekolah, Jakarta : PT. Rineka Cipta, 2004

Tim Redaksi Kamus Besar Bahasa Indonesia, Kamus Besar Bahasa Indonesia Edisi Ketiga, Jakarta: Balai Pustaka, 2005

Tha'imah, Rusydi Ahmad, Ta'lim al-'Arabiyah li Ghairi al-Nuthiqina biha Manahiju wa Asalibuhu, Rabath: Mansyuror al-Munazzamahal-Islamiyah li Tarbiya wa al-'ulum wa al-Tsaafiyah, ISISCO, 19891 